\title{
Hung parliaments and the need for clearer rules of government formation
}

\author{
Petra Schleiter ${ }^{\mathrm{a}}$, Valerie Belu ${ }^{\mathrm{a}}$ and Robert Hazell ${ }^{\mathrm{b}}$ \\ (University of Oxford ${ }^{\mathrm{a}}$ and University College London ${ }^{\mathrm{b}}$ ) \\ Corresponding author: \\ Petra Schleiter \\ Professor of Comparative Politics \\ Department of Politics and International Relations \\ $\&$ St Hilda's College \\ University of Oxford \\ petra.schleiter@politics.ox.ac.uk
}

\begin{abstract}
The general elections of 2017 and 2010 produced hung parliaments in which no single party could command an overall majority; in May 2015 the UK only narrowly avoided that outcome. When a parliament is hung, more than one potential government can be viable, and the constitutional rules that determine who has the first right to form the government can thus have a decisive influence on which government forms. In the past the UK has applied several potentially contradictory rules (based on conventions and principles), which do not all follow an equally democratic logic. This status quo is problematic because it can generate political controversy and uncertainty, in addition to jeopardising the Monarch's role in the government formation process. A reform that enables parliament to elect the leader who will be tasked with the formation of the next government would resolve these problems and provide constitutional clarity.
\end{abstract}

Keywords: Government formation, hung parliament, recognition rules, formateur selection, minority government, coalition formation

Affiliations: Petra Schleiter is Professor of Comparative Politics in the Department of Politics and International Relations and St Hilda's College, University of Oxford. Valerie Belu is a doctoral student in the Department of Politics and International Relations and St Hilda's College, University of Oxford. Robert Hazell is Professor of Government and the Constitution in the Constitution Unit, University College London.

Acknowledgements: We thank the editors and Andrew Blick for helpful comments, and gratefully acknowledge the support of this research by the British Academy (Ref. CTRYFG0), the Higher Education Innovation Funding for Knowledge Exchange (DPIR Feb 2014) and the Economic and Social Research Council, Impact Acceleration Award (Ref. IAA/HEIF-DIA005). 
"This country needs a period of stability and if, as the indications have shown, ... the Conservative Party has won the most seats and probably the most votes, then it would be incumbent upon us to ensure that we have that period of stability ..." (Mrs May, Constituency Victory Speech, Maidenhead, June 8, 2017)

The general elections of 2017 and 2010 produced hung parliaments in which no single party commanded an overall majority. In May 2015, the UK only narrowly avoided that outcome. Moreover, as Mrs May's cautious pronouncement on election night in June 2017 indicates (cited above), and as the polls prior to the May 2015 election suggested, it seemed possible that the party with the most seats might not be the party with the most votes. Electoral experts view hung parliaments as increasingly likely for several reasons. First, traditional voter cleavages have been eroding for some time and between 2001 and 2015, no single-party government commanded more than 40 per cent of the vote. Second, in 2017, the voter realignment caused by Brexit and austerity changed the electoral geography and denied both the Conservatives and Labour a majority despite reaching that 40 per cent threshold.

With the election behind us, we turn to the question that preoccupies politicians once a hung parliament is returned: What rules apply to government formation negotiations in the UK in the context of a hung parliament? Which actor is accorded the privileged role of formateur (i.e., the actor officially authorized to form a government) in the bargaining process? How clear and effective are the current provisions?

When elections return no single-party majority, parties must negotiate amongst themselves to form a government which enjoys the confidence of a legislative majority. There are two potentially separate questions at stake: (i) which party or parties will form the government, and (ii) which parties are prepared to support it. The bargaining process need not result in a majority coalition - it can also result in the formation of a minority coalition, or a singleparty minority government, as in June 2017, when Theresa May sought to form a minority Conservative cabinet, and in February 1974, when Harold Wilson led a minority Labour administration. But minority governments, like majority governments, have to find a mechanism to secure parliamentary support, either on the basis of ad hoc bargaining or through a more stable supply and confidence agreement such as the Lib-Lab Pact from 1977 to 1978 .

Recognition rules regulate which actors will be asked to form the government and in what order. They determine (i) who will be formateur, i.e. the person formally tasked with the attempt at forming a government, and (ii) to whom this role will pass next, should the attempt fail. In the UK, it is the sovereign's prerogative to appoint a Prime Minister designate. The Monarch is expected to discharge this role in the government formation process without becoming involved in any negotiations - 'she is [a] recipient of advice but not an active participant.' ${ }^{1}$ This presents no challenge when a single party commands an outright legislative majority and the Prime Minister is directly identified by the election result. However, if the election returns a hung parliament, the task of naming an appropriate government formateur often involves political choices, which can crucially influence the nature of the government that is then formed. In this situation it is desirable that the procedure for government formation separates the political choices from the formal and ceremonial aspects of government formation in order to protect the Monarch from political controversy. This is not currently the case in the UK. 
This paper reviews the UK's constitutional conventions and past precedents in formateur selection, and places them in the context of six principles used by other parliamentary democracies to guide actors who participate in government formation. We show that, in the past, the UK has applied five of these six principles in selecting formateurs, and that these principles are potentially contradictory. Moreover, not all of these principles follow an equally evident democratic logic. A lack of clear and democratically robust guidance is problematic because it can spark controversy and call into question the Monarch's nonpartisan role in the government formation process.

This risk is illustrated by events in the Netherlands in 2010, when Queen Beatrix tasked several party leaders, in succession, with exploring the options for forming a coalition. The process proved difficult, contentious and protracted, ultimately entangling the Queen in charges that her political impartiality had been compromised. The controversy contributed to the Dutch parliament's 2012 decision to end the Queen's involvement in the government formation process.

In this paper, we outline options to address the problem and argue that the most appropriate mechanism to nominate a formateur is a vote in parliament, in the form of a recommendation to the Monarch. This would protect the monarchy and its political impartiality by separating the political choice of a formateur - made by parliament - from the formal act of appointing a formateur, which remains the Monarch's prerogative.

\section{Two government formations, different principles}

The UK's post-war history of government formation negotiations is short. Before the 2010 election and the resulting coalition, the need for negotiations had arisen only once, following the February 1974 general election which also resulted in a hung parliament. Heath, the incumbent Prime Minister, remained in office for four days, attempting to form an administration by offering coalition participation to the Liberals. Only when these negotiations failed did Heath resign, and Labour, the largest party by five seats, was invited to form the next government. At the time, the choice to entrust the incumbent Prime Minister (rather than the leader of the largest party) with the first attempt to form a government had cross-party approval. As Wilson, then leader of the Labour Party, wrote

There were suggestions in March 1974, that as Labour had more seats than any other party [...] the Sovereign should have sent at once for the Labour leader. This is not so. A Government was in existence, and until it resigns, following the election results, or a defeat on the Queen's speech, the Palace can only observe the classical doctrine, "We have a Government".

Yet, despite this constitutional precedent, politicians appealed to a different guiding principle during the 2010 negotiations. Nick Clegg, the leader of the Liberal Democrats, stated before the election that the party with the most votes and seats should have the initial say on forming a government. He proceeded according to this view after the election, and negotiated primarily with the Conservatives, who had won 48 more seats than the incumbent Labour Party. The difference between the two principles that were applied by political actors in negotiating government formation concerns the nature of the UK's recognition rules.

\section{Recognition rules: importance, variation, challenges}


Recognition rules are the constitutional principles that determine which actor is asked to form the government - i.e., to assume the role of the formateur - and in what order different actors are invited to take on this role. These constitutional rules have political consequences: they condition the probability with which different parties enter the government and affect a government's majority and coalition status.

Recognition rules vary across several dimensions. (i) The power to designate the formateur may lie directly with parliament, or involve the head of state (the Monarch or the President).

(ii) The discretion that these actors enjoy in selecting the formateur may vary: in some countries they have little leeway because their choice is precisely dictated by constitutional law or by well-established customs; in other countries the rules are less codified, giving actors more freedom in their decision. (iii) The legal status of recognition rules can vary. They may take the form of constitutional law or convention.

Recognition rules like those in the UK, which give the Monarch a formal role in the process of government formation, present special challenges. Because monarchs are not democratically elected, there is a broad consensus that the Monarch must remain politically impartial (and be perceived as such). This places a particular onus on the recognition rules to protect the Monarch from having to make political choices. When the rules and principles that guide a Monarch's choices contradict each other, or yield results that are perceived as democratically problematic, government formation choices can become contested.

Contradictory rules and principles can place monarchs under tremendous pressure, which may result in the exercise of personal discretion. This is illustrated by King George V's role in the government formation process that followed the split and collapse of the minority Labour government in 1931. In the context of the Great Depression, the King feared the disruption of an election and the possibility that Britain might be forced off the gold standard. As a result, he repeatedly refused to accept the resignation of the incumbent Prime Minister, Ramsay McDonald, and pressed for the formation of a coalition, the National government, under McDonald's leadership. The decision proved controversial, resulted in McDonald's expulsion from the Labour Party, and caused significant reputational damage to the monarchy.

Today, the UK Cabinet Manual seeks to rule out all personal discretion. It envisages that a Monarch acts on the advice of politicians (i.e., ministers and party leaders), channelled through the Monarch's private secretary. However, contradictory rules can leave that advice contestable, and may make the Monarch vulnerable to the charge of having favoured a particular outcome. Below, we review the different recognition principles that can be invoked, and chart how they have been used in the UK in the past to select the formateur. To illustrate the contradictions between these rules and how they can give rise to controversy, we rely on some potential outcomes for which parties were preparing before the 2015 general election, based on the predictions of the polls.

\section{Hung parliament projections in 2015}

In the last 21 days before the 2015 UK general election, ukgeneralelection.com and ukelect.co.uk were predicting the following seat and vote distributions: 
Table 1: Predicted seat and vote distributions, UK general election, May 2015

\begin{tabular}{ccc}
\hline Party & Seats $\dagger$ & Vote share $\dagger \dagger$ \\
Conservatives & 275 & $33.5 \%$ \\
Labour & 273 & $34 \%$ \\
SNP & 47 & \\
Liberal Democrats & 28 & $8.5 \%$ \\
UKIP & 3 & $13 \%$ \\
\hline
\end{tabular}

Sources: $\nmid$ http://ukgeneralelection.com/2015/05/07/final-prediction/; $\dagger \dagger$

http://www.ukelect.co.uk/HTML/forecasts/20150412ForecastUK.html

These forecasts, like nearly all other forecasts, showed neither main party securing the required majority of 326 seats. They also envisaged that Labour would have won fewer seats than the Conservatives, but the largest vote share. Now imagine the following scenario: as the election result becomes clear, the Conservative Prime Minister, Mr Cameron, claims the right to govern and argues that it would be 'illegitimate' for Labour, as the party that came second in terms of seats, to form a government. Labour argues that a Conservative-led government, which has lost votes and seats compared with 2010 (when the Conservatives won 307 seats and 36.1 per cent of the vote), would be a 'government of election losers,' and that Labour should be given the right to form a government. After bargaining between the parties two viable camps emerge: one led by the Conservatives, and one by Labour. Neither side concedes defeat. In this scenario who would govern?

\section{Six recognition principles}

Comparative studies in political science identify six principles that are applied to select a formateur when an actor other than parliament itself is involved in that choice. ${ }^{3}$ Five of these principles have at some point been invoked in the UK. Three of them are reflected in the 2011 Cabinet Manual, which is currently the most comprehensive guide to the laws, conventions and rules on the operation of government.

1. The majority principle: The principle that is most frequently applied in the UK is the majority principle. It is regarded as a clear constitutional convention. As the Cabinet Manual states, governments that retain their parliamentary majority in an election normally continue in office. Moreover, '[i]f the election results in an overall majority for a different party, the incumbent Prime Minister and government will immediately resign and the Sovereign will invite the leader of the party that has won the election to form a government' (Cabinet Manual 2011, § 2.11).

2. The continuation rule: When no party achieves an overall majority, the majority principle cannot apply, so alternative conventions must be invoked. At this point the distinction between informal negotiations and the formal recognition rules becomes important. Informally, any party can negotiate with any other party about government formation in a hung parliament. But the formal recognition rules determine which actor has the 'first right' to attempt to form a government after those negotiations and to test whether it has the confidence of the legislature. The Cabinet Manual seeks to establish that the formal principle which applies in a no-majority situation is the continuation rule (Cabinet Manual 2011, $\S$ 2.12), which was appealed to by Heath and Wilson in 1974. This principle stipulates that the 'incumbent government is entitled to wait until the new parliament has met to see if it can command the confidence of the House of Commons' (Cabinet Manual 2011, § 2.12). It privileges the incumbent as the first mover in government formation. Only if it emerges that 
the incumbent is 'unlikely' or unable to command the confidence of parliament in the vote on the Queen's speech, and there is a clear alternative, is the government expected to resign.

In our illustrative scenario, this rule would have given the incumbent Prime Minister, $\mathrm{Mr}$ Cameron, the first right to form a government and test his ability to command the confidence of parliament. This rule becomes problematic, however, when the incumbent Prime Minister's party lacks the parliamentary support or legitimacy to form a government because it has lost votes and seats (as is the case in our scenario), or if it no longer controls the largest number of seats. In this case, the continuation rule conflicts with the two interpretations of the plurality principle, which will be discussed in more detail below. This principle dictates that the winner of the largest seat share (seat-based interpretation) or the largest vote share (vote-based interpretation) gets the first chance to form the government. Precisely this conflict between the continuation rule, on the one hand, and the two plurality principles, on the other, arose in 2010, when the Labour government lost votes and its parliamentary majority. Following the election, Gordon Brown, was decried as the 'squatter in Downing Street' when he did not resign instantly, despite the fact that there was a hung parliament and he was the incumbent Prime Minister.

Our scenario is more ambiguous than the situation in 2010, because it envisages that the incumbent Prime Minister, while losing votes and seats, still remains the leader of the largest parliamentary party. In this situation, Mr Cameron could have attempted to argue for the first right to form a government under the continuation rule. Labour, which would have won more votes in our 2015 scenario, could have challenged his right to do so by appealing to the votebased interpretation of the plurality principle. If neither side had conceded defeat, the continuation rule would have taken precedence and the incumbent would have formed the government. But as the 'squatter in Downing Street' episode following the 2010 elections illustrates, that choice might have triggered intense controversy and challenging legitimacy questions.

3. The gravitational principle: In practice, the resolution of such conflicts often depends on the next step in the government formation sequence. The Cabinet Manual specifies the rules in the UK as follows: if the incumbent does not form the new government, 'the Sovereign will invite the person who appears most likely to be able to command the confidence of the House to serve as Prime Minister and to form a government' (Cabinet Manual 2011, § 2.8). This is the gravitational principle, according to which the person mostly likely to succeed at the task is entrusted with forming the government. It was in fact applied in 2010, after Gordon Brown resigned and the Queen invited David Cameron to form a Conservative-led coalition government. The principle emerged as a recognition rule in the UK during the middle of the $19^{\text {th }}$ century, when the two-party system in place at the time was declining. It was revived in the first draft of the Cabinet Manual ahead of the 2010 election, when the polls were predicting a hung parliament. But because this rule potentially allows the sovereign significant discretion in choosing the formateur, which is at odds with the impartiality required of the Monarch today, it is supplemented by the following convention: 'If there is doubt, it is the responsibility of those involved in the political process, and in particular the parties represented in parliament, to seek to determine and communicate clearly to the sovereign who is best placed to be able to command the confidence of the House of Commons' (Cabinet Manual 2011, § 2.9). In other European democracies, the gravitational principle is usually viewed as the principle of last resort because it does not provide unambiguous guidance. Indeed, applied to our illustrative scenario, in which either a 
Conservative-led or a Labour-led government is viable, and neither side concedes defeat, the gravitational principle would, by definition, fail to offer sufficiently clear guidance.

4. The plurality principle: Most European democracies that are regularly governed by coalitions prioritise the plurality principle. It dictates that the largest parliamentary party should be the first to designate a formateur. Only if the first formation attempt fails should the nomination pass on to the second largest party, then to the third, and so forth. By focusing on the seat distribution in parliament as the determinant of the order in which actors are invited to form a government, this principle follows a clear democratic logic. In Europe, it is for instance applied in Finland, Belgium, the Netherlands, Sweden, Greece and Bulgaria. Note, however, that given the disproportionality of the majoritarian electoral system employed in the UK, the largest parliamentary party does not necessarily correspond to the one that won the most votes. Hence the two interpretations of this principle can identify different formateur parties. This was in fact the case in the UK in October 1951, when the Conservatives, who commanded seven seats more than Labour, went on to form the government, although Labour had polled almost a quarter of a million votes more than the combined vote of the Conservatives and their Liberal National allies. This precedent would suggest that a seat-based interpretation of the plurality principle would dominate a vote-based interpretation in our scenario, so that the Conservative Party would have exercised the first right to form the government. In practice, though, which of these equally democratically anchored principles takes precedence often depends on the political viability of the alternative governments.

\section{The culpability principle: In the $19^{\text {th }}$ century, when UK governments were frequently} ousted by no-confidence votes, a fifth principle, the culpability principle, was often applied. It envisages that the opposition party most responsible for toppling the government should form the next administration. This principle was last used in January 1924, when the Conservative government under Baldwin was defeated through a no-confidence amendment to the King's speech. As a result, the leader of the Labour party, which had initiated the amendment, was asked to form the government, even though Labour had won only a third of the vote. Asquith, the Leader of the Liberal Party, which held the balance of power in parliament at the time, declared, 'if the Labour party is willing, as I understand it is, to assume the burden of office in such conditions, it is the[ir] absolute undoubted right to claim it.' This episode is also an illustration of the plurality principle discussed above. Baldwin as leader of the largest party had tried to command the confidence of the new parliament but failed. It then fell to the leader of the second largest party, the Labour party, to try to form a government. The culpability principle has not been invoked recently because governments have used their power to dissolve parliament upon losing its confidence.

\section{The plebiscitary principle: The plebiscitary principle dictates that the party with the} greatest increase in votes gets the first chance to form the government. It is often applied in European democracies when the party identified by the plurality principle seems disqualified from forming a government because its vote or seat share has stagnated or even decreased since the preceding election, as is the case in the scenario described above. Under these circumstances, the plebiscitary principle may trump the plurality principle. This is what happened after Belgium's 1954 elections, when the Christian Social Party government lost its majority. This was seen as justifying the formation of a coalition of left parties, despite the fact that the Christian Social Party remained the strongest party in parliament. A similar situation emerged in Iceland in 1956, and led to the dissolution of a coalition between the two strongest parties, when the Conservative Independence Party lost two seats while its coalition 
partner, the Progress Party, gained one. The Progress Party appealed to the plebiscitary principle and formed a left coalition; the election had been fought over the question of the withdrawal of US troops, and even the relatively small shift in vote share was interpreted as a clear indication of the will of the people. In our example, as we have seen, the plebiscitary principle contradicts the continuation rule and the seat-based interpretation of the plurality principle. In particular, it would have given Labour a basis to claim that a Labour-led government is a government of 'election winners', while the Conservatives' mandate to govern was undermined by the withdrawal of voter support.

\section{Implications}

Recognition rules matter because government formation often involves choices of farreaching importance. During the late 1800s and early 1900s, for instance, government formation in the UK engaged the question of national unity and Irish independence - a major and deeply divisive cleavage in UK politics at the time. In May 2015 the questions of Scottish independence, English votes for English laws, and the UK's future in Europe were at stake. In June 2017 the Brexit deal, the nature of the border between Northern Ireland and the Republic of Ireland, austerity, and the future of public services formed a similarly salient divide. Because recognition rules may influence which government is formed and how such questions are resolved, these procedures should (i) be seen as democratically legitimate and (ii) protect the Monarch from controversy. These two central normative concerns have implications for the process as it currently operates in the UK, because, as we have seen above, the conventions and principles that have been applied in the past vary in their democratic rationale and potentially contradict each other.

When government formation negotiations have the potential to result in more than one viable government, this can render the sovereign's role in appointing the formateur fraught in two respects. First, any nomination in such contexts involves political judgement, which can leave the recommendation of the Queen's advisers, and by implication the Queen's decision, open to political controversy. This risk is particularly pronounced when the formateur appointment is based on a recognition rule such as the continuation rule that conflicts with alternative recognition rules (i.e., the plurality or the plebiscitary principles), which have a superior democratic justification. Second, the choice between alternative formateurs may be contested among the Monarch's advisers, especially when the political and economic context is particularly challenging - as was the case in the early 1930s. In such contexts, contradictory recognition rules can put tremendous pressure on the Monarch to exercise personal judgment in formateur selection, compromising the sovereign's political impartiality. For a monarch, the repercussions of any exercise of personal judgement can be serious. As noted above, such charges entangled Queen Beatrix of the Netherlands in political controversy and contributed to the decision of the Dutch parliament in 2012 to end the Queen's involvement in the government formation process. In sum, complex government formation processes, in combination with ambiguous recognition rules, can put a monarch in a potentially difficult and democratically problematic position. This, we argue, is a harm to be avoided. The next section outlines a government formation process that would effectively address these problems.

\section{A reform to address the problem}

Is there an alternative to the use of potentially contradictory ex ante recognition rules? Any discussion of the options might focus on three questions: 
- First, which actor and mechanism might be most appropriate for recommending a formateur?

- Second, what role for the Monarch might best protect the Queen and her political impartiality?

- Third, what procedure of formateur selection is most practical, effective and democratically defensible?

The key to the first question lies in the test that every UK government must pass in order to govern, namely, the vote on the Queen's speech, which outlines the government programme. This test ensures that no government can take power unless it can command the support of the democratically elected House of Commons. It establishes a positive expression of support in parliament as the mechanism by which governments are made (or blocked). Consequently, a vote by the same body - parliament - not advice by the incumbent government or any other adviser to the Queen, is the best mechanism to nominate a viable formateur. The House of Commons Political and Constitutional Reform Committee recently recommended a reform which would make precisely this change: the introduction of a legal requirement for a parliamentary vote to formally nominate the incoming Prime Minister (in the form of a recommendation to the Queen). ${ }^{4}$ Parliamentary selection of the formateur is common. Indeed, within the UK, it is current practice in the Welsh Assembly and the Scottish Parliament.

This reform proposal also offers an answer to the second question outlined above - how best to protect the Monarch and her political impartiality. One of the proposal's merits is that it would safeguard the neutrality of the Monarch by making the appointment of the formateur a formal act that is separated from the political choice of the formateur, which would be placed in the hands of parliament. There are precedents for the successful operation of this procedure - both the Scottish Parliament and the Welsh Assembly currently use it. Japan and Ireland, likewise, separate the formal formateur appointment (by the Emperor and President respectively), from the political choice of formateur nomination, which is made by their parliaments.

That raises the question of how parliament might choose, and vote on, potential formateurs. A direct vote in parliament to select the formateur is the simplest and quickest procedure. All parties may nominate a candidate. Parliament votes on all candidates simultaneously (each member may vote for only one candidate). The candidate who wins an absolute majority is recognised as the formateur. If no candidate wins an absolute majority either a run-off system or an elimination rule (elimination of the weakest candidate in each round) is applied in subsequent ballots to determine which candidate has the strongest support. This type of system is currently used in the Scottish Parliament and in Japan. In more complex coalition systems a degree of exploration and facilitation is often desired. In such cases, parliament may designate the Speaker or a party leader to explore what coalitions are viable (in the literature, this person is called the informateur). On the basis of this person's report and recommendation, parliament may then choose a formateur. Versions of this type of system are used by Sweden and the Netherlands (since 2012). Either approach sidesteps the awkwardness of an ex ante choice among recognition principles, which the involvement of an actor outside parliament - such as a monarch or a president - typically requires. ${ }^{5}$

In sum, as long-term changes in voter behaviour and electoral geography are making parliaments without a single-party majority more likely in the UK, clearer recognition rules, underpinned by a normative consensus, will be required. The hung parliaments of 2010 and 
2017 are unlikely to remain an exception. This makes the need to clarify the conventions guiding government formation in the UK increasingly pressing.

${ }^{1}$ Peter Riddell, cited in Nicholas Watt, "Not out of it, but above it": how the Queen will engineer a royal retreat to keep out of a hung parliament', The Guardian, 6 March 2015.

${ }^{2}$ Harold Wilson, Final Term: The Labour Government 1974-1976, London, Weidenfeld and Nicolson, 1979, p. 11.

${ }^{3}$ Klaus von Beyme, Die parlamentarischen Regierungssysteme in Europa, München, Piper, 1970, pp. 492-521. Published in English as Parliamentary democracy, Basingstoke, Macmillan, 2000. Diermeier and van Roozendaal, 1998, pp. 609-626.

${ }^{4}$ House of Commons Political and Constitutional Reform Committee, 2015, Government Formation Post-Election, HC 1023.

${ }^{5}$ For a more detailed discussion of the nomination procedure see Petra Schleiter, Valerie Belu and Robert Hazell, "Forming a government in the event of a hung parliament: The UK's recognition rules in comparative context." UCL/DPIR Policy Report, 2016, https://www.ucl.ac.uk/constitution-unit/publications/tabs/reports 